\title{
ARTIKELEN
}

\section{Lokale beleidsvrijheid: geven en nemen?}

\section{Over de relatie tussen formele beleidsvrijheid, ambtelijke capaci- teit, schaal en politieke verandering}

\author{
Jolijn De Roover, Jan Wynen, Wouter Van Dooren \& Jan Boon
}

\begin{abstract}
Lokale beleidsvrijheid wordt vaak gelijkgesteld aan de formele beleidsvrijheid van gemeenten en dus aan de formele grenzen die het lokale speelveld bepalen. In dit artikel stellen we deze aanpak ter discussie. Het is namelijk onduidelijk in welke mate formele beleidsvrijheid een goede maat is voor de 'echte' beleidsvrijheid van gemeenten, en dus voor de beleidsvrijheid die gemeenten benutten in de beleidsvoering. Leidt meer formele beleidsvrijheid noodzakelijk tot meer gebruikte beleidsvrijheid? Bovendien benut niet elke gemeente de formele beleidsvrijheid op dezelfde manier. Om variantie in gebruikte beleidsvrijheid te duiden wordt vaak verwezen naar ambtelijke capaciteit, schaal en politieke veranderingen. Toch is het onduidelijk in welke mate deze variabelen een impact hebben op de lokale beleidsvrijheid. We onderzoeken de link tussen formele en gebruikte beleidsvrijheid, ambtelijke capaciteit, schaal en politieke verandering aan de hand van een Vlaamse beleidshervorming. Op basis van een analyse van financiële data concluderen we dat meer formele beleidsvrijheid een stimulans kan zijn voor meer gebruikte beleidsvrijheid, maar ook dat de verklarende kracht van ambtelijke capaciteit, schaal en politieke verandering beperkt is. Zowel in onderzoek als in beleid moet meer aandacht gaan naar de relevantie van sociale interactie, soft skills en netwerken.
\end{abstract}

Drie punten van relevantie voor beleidsmakers: (a) lokale beleidsvrijheid is niet enkel afhankelijk van formele beleidsvrijheid, maar ook van de mate waarin gemeenten gebruik weten te maken van die vrijheid; (b) meer formele beleidsvrijheid kan een stimulans zijn voor meer gebruikte beleidsvrijheid, maar ook andere, niet formele aspecten (bijv. netwerken, sociale interactie) hebben mogelijk een impact; (c) niet alle gemeenten gebruiken hun beleidsvrijheid in dezelfde mate. Vaak gebruikte verklaringen - i.e. ambtelijke capaciteit, schaal en politieke verandering - blijken statistisch vrij weinig te verklaren.

\section{Inleiding}

Lokale beleidsvrijheid heeft sinds enkele decennia een belangrijke plaats veroverd op de beleidsagenda van heel wat Europese landen. Het zou lokaal maatwerk mogelijk maken, de fiscale discipline van gemeenten versterken, beleid dichter bij de burger brengen en zorgen voor meer efficiëntie en effectiviteit (Asatryan e.a., 2015; De Mello, 2000; Eyraud \& Lusinyan, 2013; Greffe, 2006; Hansen \& Klausen, 
2002; Hills, 1997; Hooghe \& Marks, 2012; Larson \& Ribot, 2004; Pratchett, 2004; Tiebout, 1956). Om dit alles te bereiken breiden centrale overheden vaak de formele beleidsvrijheid van gemeenten uit. Zo wordt lokale beleidsvrijheid vaak gelijkgesteld aan de formele grenzen die het lokale speelveld bepalen. In dit artikel stellen we deze aanpak ter discussie. Meer formele beleidsvrijheid is immers niet voldoende om de doelstellingen van lokale beleidsvrijheid te realiseren: gemeenten moeten de formele beleidsvrijheid ook gebruiken in de beleidsvoering. Formele beleidsvrijheid bepaalt het speelveld waarbinnen lokale besturen ${ }^{1}$ eigen beleid mogen maken, maar zegt niets over de mate waarin gemeenten die ruimte benutten. In dit artikel leggen we daarom de link tussen formele en gebruikte beleidsvrijheid en stellen we de vraag: leidt meer formele beleidsvrijheid noodzakelijk tot meer gebruikte beleidsvrijheid?

Bovendien gebruiken gemeenten de beleidsvrijheid niet noodzakelijk op dezelfde manier. Om variantie in gebruikte beleidsvrijheid te duiden wordt vaak verwezen naar ambtelijke capaciteit, schaal en recente politieke veranderingen. Toch is het onduidelijk in welke mate deze variabelen een impact hebben op de lokale beleidsvrijheid. We stellen daarom ook de vraag in welke mate ambtelijke capaciteit, schaal en politieke verandering de variantie in het gebruik van beleidsvrijheid verklaren.

De empirische context is een beleidshervorming die de formele beleidsvrijheid van Vlaamse gemeenten in 2016 aanzienlijk heeft vergroot. In 2016 heeft de Vlaamse overheid zeven sectorale subsidies omgevormd tot basisfinanciering. ${ }^{2}$ De 300 Vlaamse gemeenten krijgen de subsidies nog steeds, maar zijn sinds 2016 niet langer verplicht om verantwoording af te leggen over de besteding ervan. De hervorming biedt dan ook een unieke kans om beleidsvrijheid te onderzoeken: besteden Vlaamse gemeenten de subsidies anders sinds ze beschikken over de nodige formele beleidsvrijheid? We operationaliseren gebruikte beleidsvrijheid als verschuivingen in uitgavenpatronen en gebruiken, in tegenstelling tot het meeste onderzoek naar beleidsvrijheid, longitudinale data (2014-2025) van alle Vlaamse lokale besturen $(\mathrm{N}=300)$. We focussen dan ook op één element van lokale beleidsvrijheid: de lokale afwijking van beleid dat eerder centraal was.

In de volgende sectie gaan we dieper in op formele en gebruikte beleidsvrijheid (paragraaf 2) om vervolgens de Belgische casus en de methodologie toe te lichten (paragraaf 3). Daarna bespreken we de resultaten van de statistische analyses (paragraaf 4 ) en reflecteren we op de bevindingen in de discussie en conclusie (paragraaf 5).

1 Dit artikel gaat over de beleidsvrijheid van gemeenten. Met de term 'lokale besturen' verwijzen we naar gemeenten en niet naar het provinciale niveau of andere instituties.

2 De geoormerkte subsidies zijn sinds 2016 onderdeel van het Gemeentefonds in de vorm van een aanvullende dotatie. Het betreft de geoormerkte subsidies voor de beleidsvelden: sport, jeugd, cultuur, flankerend onderwijs, kinderarmoede, ontwikkelingssamenwerking en integratie. 


\section{Formele en gebruikte beleidsvrijheid}

Zowel in beleid als in onderzoek naar lokale beleidsvrijheid ligt de focus doorgaans op de formele grenzen waarbinnen gemeenten geacht worden beleid te maken. Formele beleidsvrijheid omvat (1) de mate waarin steden en gemeenten hun eigen takenpakket kunnen samenstellen, (2) de mate waarin lokale besturen invloed hebben op beleid dat zij belangrijk vinden, (3) de juridische basis om lokale beleidsvrijheid te laten gelden in de praktijk, en (4) de mate waarin lokale besturen gecontroleerd worden door een centrale overheid (Ladner e.a., 2019).

De grenzen van het lokale speelveld worden geanalyseerd om zo de vrije bewegingsruimte van gemeenten in kaart te brengen (Lake, 1994; Painter \& Yee, 2010). Onderzoek heeft aangetoond dat de formele beleidsvrijheid van gemeenten afhankelijk is van de mate waarin ze fiscale inkomsten kunnen vergaren, de vrijheid waarover ze beschikken om middelen naar eigen goeddunken te besteden en de mate waarin ze blootgesteld zijn aan centrale controle (Fleurke \& Willemse, 2004, 2006; Keuffer \& Horber-Papazian, 2019).

In het meeste onderzoek naar lokale beleidsvrijheid bestaat de verwachting dat formele kaders de beleidsvrijheid van gemeenten bepalen. De formele kaders bepalen immers welke actor welke taak op welke manier moet uitvoeren (Egeberg \& Trondal, 2009; Painter \& Yee, 2010). Volgens deze logica vertaalt formele beleidsvrijheid zich per definitie in gebruikte beleidsvrijheid. We formuleren daarom de volgende theoretische verwachting:

H1: Er bestaat een significante relatie tussen formele en gebruikte beleidsvrijheid.

Toch is het onduidelijk of gemeenten zich steeds houden aan de formele grenzen van het speelveld. Zo tonen Fleurke en Willemse (2006) - een van de weinige studies naar gebruikte lokale beleidsvrijheid - aan dat gemeenten soms meer beleidsvrijheid gebruiken dan formele indicatoren voorspellen. Door beleidsvrijheid louter vanuit een formeel perspectief te benaderen bestaat dan ook het risico dat we de échte beleidsvrijheid van gemeenten onderschatten.

Ook onderzoek naar de beleidsvrijheid van agentschappen ${ }^{3}$ toont dat formele beleidsvrijheid niet noodzakelijk de beste maatstaf is voor beleidsvrijheid in de beleidsvoering. Beleidsvrijheid zou immers een sociaal construct zijn in plaats van iets dat wordt gegeven door een centrale overheid (Busuioc, 2009; Christensen \& Lægreid, 2006; Groenleer, 2009; Maggetti, 2007, 2012; Verhoest, 2017; Yesilkagit \& Van Thiel, 2008; Zito, 2015). Formele kaders zijn niet sluitend: taken en doelstellingen zijn vaak niet tot in detail gedefinieerd en ook de interacties met externe actoren laten variatie toe (Groenleer, 2009). Beleidsvrijheid krijgt daardoor ook vorm via de interactie tussen de agentschappen en de centrale overheid.

3 Een agentschap is een verzelfstandigd onderdeel binnen een ministerie welke een eigen directie, begroting en administratie heeft. 
Niet enkel de centrale overheid blijkt echter belangrijk, ook de publieke opinie, belangengroepen, media en het middenveld hebben mogelijks een impact (Gurr \& King, 1987; Jackson, 2014; Ladner e.a., 2019). Al deze actoren hebben impact op zowel de definiëring van beleidsproblemen als op de mogelijke oplossingen (Fleurke \& Willemse, 2004; Maestas e.a., 2020; Sedmihradska \& Bakos, 2016). Hierdoor kan de gebruikte beleidsvrijheid soms groter of kleiner zijn dan wat de formele kaders toelaten. We testen daarom een alternatieve verwachting:

H1.alternatief: Er bestaat geen significante relatie tussen formele en gebruikte beleidsvrijheid.

Uiteraard bestaan er heel wat verschillen tussen lokale besturen en agentschappen. Zo worden lokale besturen democratisch verkozen en agentschappen aangesteld. Dit maakt dat gemeenten zowel van onderuit, via het kiespubliek, als van bovenuit, via een centrale overheid, gecontroleerd worden, terwijl de controle van agentschappen voornamelijk van bovenuit komt. Bevindingen over agentschappen kunnen dus niet zomaar gebruikt worden om de beleidsvrijheid van lokale besturen te beschrijven, maar kunnen wel een belangrijk startpunt bieden. De bottom-up controle waar gemeenten aan blootgesteld zijn, maakt het immers nog belangrijker om ook in onderzoek naar de lokale beleidsvrijheid voorbij formele kaders te kijken en te onderzoeken hoe gemeenten de beleidsvrijheid benutten.

Niet alle gemeenten gebruiken hun beleidsvrijheid op dezelfde manier. Sommige gemeenten benutten meer vrije speelruimte dan andere. Om dit te verklaren verwijzen beleidsmakers en onderzoekers vaak naar variantie in ambtelijke capaciteit, schaal en politieke verandering.

Ambtelijke capaciteit zou het gebruik van beleidsvrijheid faciliteren aangezien het de basis biedt om in te spelen op de veranderlijke lokale context (Börzel e.a., 2010; Hulst \& Van Montfort, 2007; Koch \& Molenaers, 2016; McAllister, 2010). Ambtelijke capaciteit verwijst naar het vermogen om beleidsuitdagingen en kansen te herkennen, om relevante actoren samen te brengen, om beleidsalternatieven af te wegen en om beleid succesvol en efficiënt te implementeren (Nelles, 2013). Om in dat opzet te slagen heeft een lokaal bestuur personeel nodig. Daarom operationaliseren heel wat onderzoekers ambtelijke capaciteit als het aantal voltijds equivalenten (VTE) per capita (Fernandez e.a., 2008; Gerber \& Hopkins, 2011; Verschuere \& De Corte, 2015). We volgen deze strategie en testen of ambtelijke capaciteit in termen van VTE per 100 capita bijdraagt aan het gebruik van beleidsvrijheid:

H2: Lokale besturen met meer VTE per 100 capita gebruiken meer formele beleidsvrijheid.

Naast ambtelijke capaciteit wijzen beleidsmakers en onderzoekers ook vaak naar schaal - doorgaans gemeten als inwonersaantal - om variantie in gebruikte beleidsvrijheid te verklaren (Hulst \& Van Montfort, 2007; Walker e.a., 2015). Burgers hebben verwachtingen: ze willen sporten in de wijk, genieten van kwaliteitsvolle culturele activiteiten en hun kinderen op een veilige manier laten spelen. Wanneer 
burgers tevreden zijn met de gemeentelijke dienstverlening, staan ze niet altijd te springen om verandering. Mensen geven immers doorgaans de voorkeur aan een situatie waarmee ze vertrouwd zijn (Cao e.a., 2011) en waarvan ze weten dat het hun behoeften zal bevredigen (Wildavsky \& Dake, 1990). Deze voorkeur voor zekerheid kan een rem zijn op het gebruik van beleidsvrijheid. Met name in kleine gemeenten, waar de sociale afstand tussen burger en bestuur kleiner is en de bottom-up controle sterker. In grotere gemeenten zou er meer sociale afstand bestaan tussen het bestuur en de burgers, wat de mogelijke bottom-up controle richting het lokaal bestuur beperkt. Om die reden testen we een derde theoretische verwachting:

\section{H3: Grotere lokale besturen gebruiken meer formele beleidsvrijheid.}

Toch is ook de omgekeerde redenatie mogelijk. In kleine gemeenten staan bestuurders dichter bij het lokale netwerk, waardoor ze mogelijk nog beter weten waar lokaal maatwerk nodig is. Bovendien zorgt de beperkte afstand tussen burger en bestuur ervoor dat bestuurders sneller worden aangesproken door burgers. Indien bestuurders beschikken over voldoende beleidsvrijheid, kunnen de nauwe banden tussen burger en bestuur ook een stimulans zijn voor het gebruik van beleidsvrijheid, zeker als de burger ontevreden is met het huidige beleid en de huidige dienstverlening. Als de huidige situatie niet bevredigend is, is de angst voor het onbekende een minder groot probleem. We testen daarom ook een alternatieve versie van de derde theoretische verwachting:

H3.alternatief: Lokale besturen met een kleinere schaal gebruiken meer formele beleidsvrijheid.

Ten slotte, ook politieke verandering wordt vaak aangehaald om variantie in gebruikte beleidsvrijheid te duiden. Echte beleidsverandering zou immers slechts gerealiseerd worden als een nieuw team van politici het roer overneemt (Dewan \& Myatt, 2007; Galasso \& Nannicini, 2011; Jones \& Olken, 2005). Er bestaat heel wat empirisch onderzoek dat aantoont dat nieuwe burgemeesters meer beleidsveranderingen doorvoeren dan hun voorgangers (zie bijv. De Benedictis-Kessner \& Warshaw, 2016; Gerber \& Hopkins, 2011; Wolman e.a., 1996). Volgens Burstein en Linton (2002) is een positieve correlatie tussen politieke verandering en beleidsverandering een kenmerk van een goed functionerende democratie. Verkiezingscampagnes zouden immers moeten leiden tot nieuwe beleidsagenda's, welke vervolgens het beleid bepalen (Burstein \& Linton, 2002; Wolman e.a., 1996) op voorwaarde dat bestuurders beschikken over voldoende beleidsvrijheid. Daarom testen we een vierde theoretische verwachting:

H4: Gemeenten die politieke verandering hebben doorgemaakt, benutten meer beleidsvrijheid.

We operationaliseren politieke verandering als een nieuwe burgemeester die lid is van een andere politieke partij dan zijn of haar voorganger. De focus ligt op een 
nieuwe burgemeester aangezien deze de meest centrale politieke rol bekleedt binnen de Vlaamse lokale besturen. Met de wil om zich te onderscheiden van zijn voorganger (Wolman e.a., 1996) is de burgemeester de uitgelezen persoon om beleidsverandering te initiëren. We houden bovendien ook rekening met de politieke partij waarvan de burgemeester lid is. Als een nieuwe burgemeester meer beleidsvrijheid gebruikt om zijn of haar beleidsagenda na te streven, zal dit het sterkst meetbaar zijn wanneer de burgemeester niet enkel van persoon, maar ook van politieke kleur verandert.

Toch bevestigt niet al het empirisch onderzoek de impact van politieke verandering (Ferreira \& Gyourko, 2009, 2014; Hopkins \& McCabe, 2012; Morgan \& Watson, 1995). De beleidsrelevantie van politieke partijen zou verloren zijn gegaan (Wattenberg, 2000) ten voordele van actoren zoals de media, belangengroepen, burgers en het middenveld (Cottle, 2008; Huckfeldt e.a., 1993; Lipsky, 1993, 2010; Peters, 1998). Bovendien bestaan er naast de formele kaders heel wat andere nationale, internationale, administratieve en economische beperkingen op de lokale beleidsvrijheid (Leigh, 2008; Morgan \& Watson, 1995; Mulé, 2001; Schmidt, 1996; Self, 2005). Zo zijn lokale besturen in de praktijk vaak afhankelijk van externe actoren of andere overheidsniveaus om beleid te realiseren, worden ze geconfronteerd met concurrentie tussen gemeenten waardoor ze hun belastinginkomsten niet zomaar kunnen verhogen en moeten ze hun financieel evenwicht bewaren (Bailey \& Rom, 2004; Berman, 2019; Craw, 2006; Ferreira \& Gyourko, 2009; Gerber \& Hopkins, 2011; Meier \& England, 1984; Nivola, 1996; Pelissero e.a., 2000; Rae, 2003; Tausanovitch \& Warshaw, 2014). Zowel nieuwe als 'oude' burgemeesters worden geconfronteerd met deze beperkingen, wat maakt dat nieuwe burgemeesters niet noodzakelijk vrij zijn om hun beleidsagenda te realiseren ondanks voldoende formele beleidsvrijheid. Het is dan ook de vraag of politieke verandering wel degelijk een positieve impact heeft op de beleidsvrijheid die lokale besturen gebruiken. Daarom testen we een alternatieve versie van de vierde theoretische verwachting:

H4.alternatief: Er bestaat geen significante correlatie tussen politieke verandering en gebruikte beleidsvrijheid.

\section{Case, data en methoden}

\subsection{Case}

We onderzoeken de theoretische verwachtingen aan de hand van een beleidshervorming in België (Vlaanderen) die de formele beleidsvrijheid van Vlaamse gemeenten aanzienlijk heeft vergroot. In 2016 besloot de Vlaamse overheid om zeven geoormerkte subsidies om te vormen tot basisfinanciering. Vlaamse gemeenten krijgen de subsidie nog steeds, maar zijn sinds 2016 niet langer verplicht om verantwoording af te leggen over de besteding ervan.

Voor 2016 beperkte de geoormerkte subsidiëring de formele beleidsvrijheid van Vlaamse gemeenten op minstens vier manieren. Ten eerste, lokale besturen moesten in hun meerjarenplanning aangeven hoe ze Vlaamse beleidsprioriteiten zou- 
den realiseren alvorens in aanmerking te komen voor de geoormerkte subsidiëring. ${ }^{4}$ Voor het sport-, jeugd- en cultuurbeleid waren er respectievelijk vier, drie en vier Vlaamse beleidsprioriteiten. ${ }^{5}$ Sinds 2016 zijn de Vlaamse beleidsprioriteiten niet langer een voorwaarde om in aanmerking te komen voor de subsidiëring en zijn gemeenten vrij om autonoom de gewenste beleidsdoelstellingen te definiëren.

Ten tweede, gemeenten waren verplicht om de subsidie volledig te besteden aan de Vlaamse beleidsprioriteiten. Beleidsdoelstellingen die niet rechtstreeks verbonden waren met de Vlaamse beleidsprioriteiten, moesten gefinancierd worden met andere middelen. Sinds 2016 zijn de geoormerkte subsidies niet langer gebonden aan Vlaamse beleidsdoelstellingen of specifieke beleidsvelden.

Ten derde, om voor 2016 in aanmerking te komen voor de geoormerkte subsidiëring moest de bevoegde Vlaamse minister de lokale meerjarenplanning en budgettering goedkeuren. De bevoegde Vlaamse administratie onderzocht ex-ante in welke mate de geplande gemeentelijke inspanningen in lijn waren met de Vlaamse beleidsdoelstellingen. Slechts als de meerjarenplanning en budgettering goedgekeurd werden, gold het recht op de subsidiëring. Sinds 2016 bestaan de voorwaarden om de subsidie te verwerven niet langer.

Ten vierde, voor 2016 moesten gemeenten ex-post verantwoording afleggen over het gebruik van de geoormerkte subsidies. ${ }^{6}$ Als de Vlaamse overheid oordeelde dat de verantwoording onvoldoende of onduidelijk was, kon ze om extra verduidelijking vragen, verdere financiering weigeren en zelfs eerder uitbetaalde middelen terugvorderen. ${ }^{7}$ Sinds 2016 worden de financiële jaarrapporten niet langer gecontroleerd als voorwaarde voor de subsidiëring.

Tabel 1 Formele beleidsvrijheid voor en na 2016

\begin{tabular}{lll}
\hline & $\ldots-\mathbf{2 0 1 5}$ & 2016-... \\
\hline Beleidsprioriteiten & Vlaams & Lokaal \\
Gebruik subsidie & $\begin{array}{l}\text { Aan Vlaamse beleidsprioriteiten } \\
\text { en specifieke beleidsvelden }\end{array}$ & $\begin{array}{l}\text { Aan alle mogelijke beleidsdoel- } \\
\text { stellingen of beleidsvelden }\end{array}$ \\
Ex-ante controle & $\begin{array}{l}\text { Via meerjarenplanning en } \\
\text { budgettering }\end{array}$ & Niet langer in werking \\
Ex-post controle & Via financiële jaarrapporten & Niet langer in werking \\
\hline
\end{tabular}

De beleidshervorming van 2016 heeft de geoormerkte subsidies richting zeven beleidsvelden omgevormd: sport, jeugd, cultuur, flankerend onderwijs, kinderarmoede, ontwikkelingssamenwerking en integratie. We analyseren de lokale uitgaven aan het sport-, jeugd- en cultuurbeleid. Van de zeven beleidsvelden waren de geoor-

4 Decreet van 15 juli 2011 houdende vaststelling van de algemene regels waaronder in de Vlaamse Gemeenschap en het Vlaamse Gewest periodieke plan- en rapporteringsverplichtingen aan lokale besturen kunnen worden opgelegd.

$5 \quad$ Kijk voor de beleidsprioriteiten in de bijlage bij dit artikel.

$6 \quad$ Art. 10 van het Decreet van 15 juli 2011.

$7 \quad$ Art. 11 van het Decreet van 15 juli 2011. 
merkte subsidies richting deze drie beleidsvelden het grootst en zo goed als alle gemeenten kregen geoormerkte subsidies voor deze drie beleidsvelden. Tabel 2 toont dat in 2014 respectievelijk 64,7\%, 13,62\% en 10,96\% van de geoormerkte subsidies naar het cultuur-, jeugd- en sportbeleid ging (Rekenhof, 2019).

\section{Tabel 2 Omvang geoormerkte subsidie, aandeel per beleidsveld en aantal lokale besturen die de subsidie kregen (Rekenhof, 2019)}

\begin{tabular}{llll}
\hline Beleidsveld & $\begin{array}{l}\text { Omvang } \\
\text { subsidie }\end{array}$ & $\%$ & $\begin{array}{l}\text { Aantal lokale } \\
\text { besturen }\end{array}$ \\
\hline Cultuur & $84.465 .000,0$ & $64,78 \%$ & 297 \\
Jeugd & $17.752 .922,5$ & $13,62 \%$ & 299 \\
Sport & $14.291 .660,6$ & $10,96 \%$ & 295 \\
Integratie & $6.042 .180,0$ & $4,63 \%$ & 56 \\
Kinderarmoede & $4.108 .746, \mathrm{I}$ & $3,15 \%$ & 67 \\
Ontwikkelingssamenwerking & $2.426 .827,5$ & $\mathbf{1}, 86 \%$ & 89 \\
Flankerend onderwijs & $\mathbf{1 . 3 0 3 . 0 0 0 , 0}$ & $\mathbf{1 , 0 0 \%}$ & 35 \\
Totaal & $\mathbf{1 3 0 . 3 9 0 . 3 3 6 , 7}$ & $\mathbf{1 0 0 , 0 0 \%}$ & $\mathbf{3 0 I}$ \\
\hline
\end{tabular}

\subsection{Data en methoden}

We operationaliseren de beleidsvrijheid die gemeenten gebruiken als veranderingen in de lokale uitgavenpatronen. De hervorming van 2016 heeft gemeenten immers meer formele beleidsvrijheid gegeven om de subsidies vrij te besteden. We focussen daarom op de lokale afwijkingen van 'eerder' centraal beleid. ${ }^{8}$

Van elke gemeente vergelijken we de originele budgettering (i.e. de budgettering opgemaakt aan de start van de legislatuur) van de meerjarenplannen 2014-2019 en 2020-2025 voor het sport-, jeugd- en cultuurbeleid. We beschikken over data van alle Vlaamse lokale besturen $(\mathrm{N}=300) .{ }^{9}$ Lokale besturen stellen de budgettering samen in het eerste jaar van de legislatuur. Dit betekent respectievelijk in 2013 en 2019 voor meerjarenplannen 2014-2019 en 2020-2025. In 2016 werd de hervorming van de geoormerkte subsidies geïmplementeerd. De originele meerjarenplanning 2014-2019 weerspiegelt daarom de situatie ten tijde van de oormerking, meerjarenplanning 2020-2025 is de eerste budgettering zonder oormerking.

8 We erkennen dat deze operationalisering niet sluitend is: gemeenten kunnen hun beleidsvrijheid ook gebruiken om het bij de oude, Vlaamse beleidsprioriteiten te houden. Vanuit de gemeenten bestond echter een duidelijke vraag om de Vlaamse beleidsprioriteiten niet langer toe te passen omdat deze niet voldoende afgestemd waren op de lokale beleidscontext. Op het niveau van de individuele gemeente is het plausibel dat enkelen de grotere beleidsvrijheid gebruiken om het bij de Vlaamse doelstellingen te houden, maar op populatieniveau (i.e. meer dan 300 gemeenten) is dit eerder onwaarschijnlijk.

9 We hebben de data verkregen via het BBC-dataplatform, i.e. het boekhoudkundige platform van lokale besturen. Alle lokale besturen zijn verplicht om de boekhouding via de BBC-tool bij te houden. Enkele gemeenten hebben we niet meegenomen in de analyse. In 2018 zijn vijftien gemeenten gefusioneerd tot zeven nieuwe gemeenten. Voor de vergelijkbaarheid tussen de meerjarenplannen hebben we de fusiegemeenten niet meegenomen. We hebben ook 'outliers' en gemeenten die de BBC-tool voor het sport-, jeugd- of cultuurbeleid niet naar behoren hebben ingevuld, verwijderd uit de analyse. 
We beschikken over de budgetten op het niveau van de beleidsdoelstellingen, de actieplannen en de concrete acties. Het meest gedetailleerde niveau - de acties - is het niveau waarop we de analyses baseren. Dat laat ons immers toe om op gedetailleerde wijze beleidsveranderingen in kaart te brengen. ${ }^{10}$ Figuur 1 geeft een overzicht van de structuur van de data.

\section{Figuur 1 Structuur van de data}

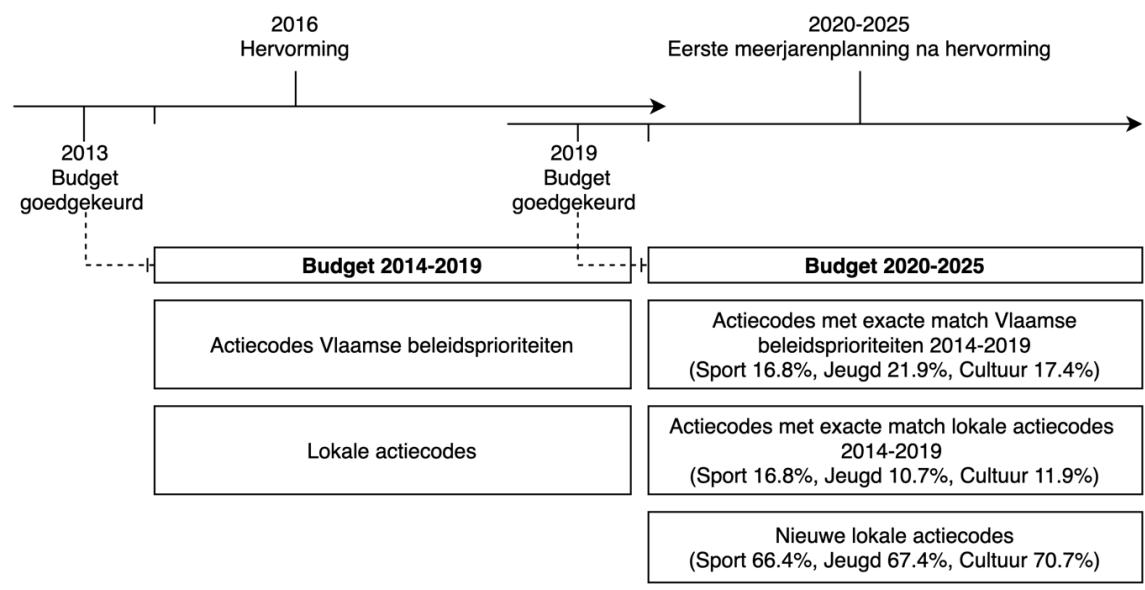

Tabel 3 toont het aantal en het aandeel beleidsacties die we hebben gebruikt in de analyse.

Tabel 3 Aantal initiële observaties en observaties met een exacte match; de matching is gebaseerd op de omschrijving van de beleidsacties in meerjarenplan 2014-2019

\begin{tabular}{lllll}
\hline & Periode & $\begin{array}{l}\text { Aantal } \\
\text { initiële } \\
\text { observaties }\end{array}$ & $\begin{array}{l}\text { Aantal } \\
\text { matching } \\
\text { observaties }\end{array}$ & \% gebruikt \\
\hline Sport & $2014-2019$ & 34.174 & $/$ & $100 \%$ \\
& $2020-2025$ & 25.516 & 8573 & $33,6 \%$ \\
Jeugd & $2014-2019$ & 33.295 & $/$ & $100 \%$ \\
& $2020-2025$ & 24.507 & 7998 & $32,6 \%$ \\
Cultuur & $2014-2019$ & 63.601 & $/$ & $100 \%$ \\
& $2020-2025$ & 52.138 & 15297 & $29,3 \%$ \\
\hline
\end{tabular}

Voor 2016 moesten gemeenten een code geven aan beleidsacties die bijdroegen aan een Vlaamse beleidsprioriteit. Elke Vlaamse beleidsprioriteit had een unieke code. Door de hervorming in 2016 zijn de codes niet langer beschikbaar in meerjaren-

10 Enkele voorbeelden van beleidsacties zijn: 'het district organiseert jaarlijks een feest voor de huwelijksjubilarissen' en 'het aanleggen van een inventaris van alle kunstenaars, amateurkunstenaars en uitvoerend kunstenaars'. 
plan 2020-2025. Toch hebben we ook voor de tweede meerjarenplanning de codes nodig, aangezien deze aantonen aan welke Vlaamse beleidsprioriteit een actie al dan niet gelinkt was voor 2016. Om dit probleem op te lossen hebben we de beleidsacties van meerjarenplan 2020-2025 'gematcht' met de beleidsacties van meerjarenplan 2014-2019 op basis van de actie-omschrijving. Ruwweg 30\% van de omschrijvingen van de beleidsacties in meerjarenplan 2020-2025 was identiek aan die in meerjarenplan 2014-2019. We hebben vervolgens de identieke beleidsacties opgedeeld in twee groepen: de Vlaamse en de lokale beleidsacties. De Vlaamse acties zijn de beleidsacties die gelinkt zijn aan een Vlaamse beleidsprioriteit en dus voor 2016 werden gesubsidieerd via de geoormerkte subsidiëring. De lokale acties zijn beleidsacties die niet gelinkt zijn aan een Vlaamse beleidsprioriteit en weerspiegelen daarom 'echt' lokaal beleid.

Om in kaart te brengen of lokale besturen de grotere formele beleidsvrijheid gebruiken, voeren we een Wilcoxon Rank-Sum-test uit. De Wilcoxon Rank-Sum-test geeft aan of het lokaal bestuur significante veranderingen heeft doorgevoerd in het budget dat ze hebben gereserveerd voor de Vlaamse en lokale beleidsacties (20142019 vs. 2020-2025)..$^{11}$

Vervolgens willen we ook te weten komen in welke mate ambtelijke capaciteit, schaal en politieke verandering een impact hebben op de mate waarin gemeenten de formele beleidsvrijheid gebruiken. We voeren daarom een regressieanalyse uit. ${ }^{12}$ De afhankelijke variabele weerspiegelt de procentuele veranderingen in het budgetaandeel dat elke gemeente heeft gereserveerd voor Vlaamse en lokale beleidsacties verspreid in de meerjarenplannen 2014-2019 en 2020-2025..$^{13}$ Als de afhankelijke variabele negatief is, heeft de gemeente een kleiner aandeel van het budget

11 Om de vergelijkbaarheid tussen de meerjarenplannen te waarborgen, delen we per gemeente en meerjarenplan het budget voor Vlaamse en lokale beleidsacties door de som van de budgetten betreffende beide groepen acties.

12 We definiëren een regressie-model dat schat in welke mate gebruikte beleidsvrijheid, gemeten als veranderingen in het aandeel van de begroting dat gereserveerd is voor lokale beleidsacties $\mathrm{Y}$, niet louter afhangt van veranderingen in formele beleidsvrijheid, maar ook van bevolkingsomvang (Omvang), ambtelijke capaciteit (VTE per 100 capita), politieke verandering (PV) en van niet-waarneembare factoren $\varepsilon$. Om te controleren voor socio-economische kenmerken hebben we de Belfius-clusters $(\mathrm{BC})$ toegevoegd. $Y=\beta_{0}+\beta_{1}$ Omvang $+\beta_{2} V T E+\beta_{3} P V+\beta_{4} B C+\varepsilon$

13 We berekenen de afhankelijke variabele door de budgetten voor alle beleidsacties per meerjarenplan (2014-2019 en 2020-2025) en per gemeente op te tellen. Vervolgens sommeren we de budgetten voorbehouden voor de Vlaamse beleidsacties per meerjarenplan en per gemeente, alsook de budgetten voorbehouden voor de lokale beleidsacties per meerjarenplan en per gemeente. Daarna delen we de budgetten per meerjarenplan en per groep beleidsacties door het totale budget dat we berekend hebben in de eerste stap. De afhankelijke variabele bekomen we vervolgens door het aandeel voorbehouden voor Vlaamse (lokale) beleidsacties in meerjarenplan 2020-2025 te verminderen met het aandeel voorbehouden voor Vlaamse (lokale) beleidsacties in meerjarenplan 20142019. 
2020-2025 gereserveerd voor Vlaamse of lokale beleidsacties in vergelijking met meerjarenplan 2014-2019. ${ }^{14}$

\section{Resultaten}

Het eerste deel van de analyse bestaat uit de Wilcoxon Rank-Sum test met welke we in kaart brengen of lokale besturen de grotere formele beleidsvrijheid gebruiken. We vergelijken het budget voorbehouden voor de Vlaamse en lokale beleidsacties in meerjarenplannen 2014-2019 en 2020-2025. Tabel 4 toont de p-waarden voor elk van de beleidsvelden en acties, alsook de resultaten van de t-toets.

Tabel $4 \quad$ Wilcoxon Rank-Sum-test en t-test

\begin{tabular}{|c|c|c|c|c|}
\hline & Cultuur & & & \\
\hline & Wilcoxon & $\mathbf{t}$ & Pr. T \& t & $\operatorname{Pr} . T$, t \\
\hline Vlaamse acties & $\left\langle\left. 0.00\right|^{\star * \star}\right.$ & 7.15 & I & $<0.001$ \\
\hline \multirow[t]{2}{*}{ Lokale acties } & $\left\langle\left. 0.00\right|^{\star \star \star}\right.$ & -8.24 & $<0.00 \mid$ & I \\
\hline & Sport & & & \\
\hline Vlaamse acties & $\left\langle\left. 0.00\right|^{\star \star \star}\right.$ & 4.97 & I & $<0.00 \mid$ \\
\hline \multirow[t]{2}{*}{ Lokale acties } & $<\left.0.00\right|^{\star \star \star *}$ & -6.24 & $<0.00 \mid$ & I \\
\hline & Jeugd & & & \\
\hline Vlaamse acties & $\left\langle\left. 0.00\right|^{\star * *}\right.$ & 7.46 & I & $<0.00 \mid$ \\
\hline Lokale acties & $<\left.0.00\right|^{\star \star \star *}$ & -9.34 & $<0.00 \mid$ & I \\
\hline
\end{tabular}

De resultaten van de Wilcoxon Rank-Sum-test tonen dat lokale besturen significante veranderingen hebben doorgevoerd in de budgettering van de drie beleidsvelden. Betreffende de Vlaamse beleidsacties is de evolutie negatief: in vergelijking met meerjarenplan 2014-2019 hebben lokale besturen in meerjarenplan 20202025 een kleiner budgetaandeel gereserveerd voor beleidsacties die tot 2016 gesubsidieerd werden via de Vlaamse beleidsprioriteiten. Betreffende de lokale beleidsacties is de evolutie positief: in vergelijking met meerjarenplan 2014-2019 reserveren lokale besturen in meerjarenplan 2020-2025 een groter budgetaandeel voor 'echt' lokaal beleid. Lokale besturen hebben dus een aandeel van het budget dat gereserveerd werd voor Vlaamse beleidsacties verschoven naar lokale beleidsacties en zo prioriteit gegeven aan 'echt' lokaal beleid.

Het grotere budgetaandeel voor lokale beleidsacties en kleinere budgetaandeel voor Vlaamse beleidsacties ondersteunen de eerste theoretische verwachting die

14 We gebruiken een Tobit-model, waarbij we een onder- en bovengrens bepalen (min één en één). We zijn louter geïnteresseerd in de latente variabele. Volgens Cameron en Trivedi (2005) is het marginale effect het volgende:

$$
\frac{\partial E\left\{y_{i}^{*}\right\}}{\partial x_{i k}}=\beta_{k}
$$

Bijgevolg kunnen we de coëfficiënten interpreteren zoals we dat bij een lineaire regressie zouden doen. 
stelt dat wanneer lokale besturen meer formele beleidsvrijheid krijgen, ze deze beleidsvrijheid ook gaan gebruiken in de beleidsvoering. We verwerpen daarom de alternatieve theoretische verwachting die stelt dat er geen significante relatie bestaat tussen formele en gebruikte beleidsvrijheid.

In het tweede deel van de analyse brengen we in kaart hoe ambtelijke capaciteit, schaal en politieke verandering gecorreleerd zijn met gebruikte beleidsvrijheid. Omdat de budgetten voor de lokale en Vlaamse beleidsacties communicerende vaten zijn, ${ }^{15}$ hebben we het regressiemodel enkel geschat voor de lokale beleidsacties.

\section{Tabel $5 \quad$ Regressietabel}

\begin{tabular}{|c|c|c|c|}
\hline & Cultuur & Sport & Jeugd \\
\hline & $\mathbf{b} / \mathbf{t}$ & $\mathbf{b} / \mathbf{t}$ & $\mathbf{b} / \mathbf{t}$ \\
\hline \multirow[t]{2}{*}{ Aantal inwoners } & 0.000 & -0.000 & -0.000 \\
\hline & $(0.31)$ & $(-0.34)$ & $(-0.35)$ \\
\hline Belfius-code (woongemeenten = ref. cat.) & $\begin{array}{l}F(5,274)= \\
2.59^{\star \star}\end{array}$ & $\begin{array}{l}F(5,276)= \\
1.5\end{array}$ & $\begin{array}{l}\mathrm{F}(5,253)= \\
4.73^{\star \star \star}\end{array}$ \\
\hline \multirow[t]{2}{*}{ Gemeenten met concentratie eco. activiteit } & $0.113^{*}$ & 0.074 & $0.168^{\star \star}$ \\
\hline & $(2.05)$ & $(\mathrm{l} .79)$ & $(3.08)$ \\
\hline \multirow[t]{2}{*}{ Centrumsteden } & -0.018 & -0.000 & 0.269 \\
\hline & $(-0.13)$ & $(-0.00)$ & $(1.93)$ \\
\hline \multirow[t]{2}{*}{ Kustgemeenten } & $0.467^{\star \star}$ & 0.041 & $0.656^{\star \star \star}$ \\
\hline & $(2.61)$ & $(0.30)$ & $(3.77)$ \\
\hline \multirow[t]{2}{*}{ Landelijke gemeenten } & -0.010 & -0.028 & 0.046 \\
\hline & $(-0.19)$ & $(-0.68)$ & $(0.86)$ \\
\hline \multirow[t]{2}{*}{ Semi-stedelijke of agglomeratie-gemeenten } & 0.121 & 0.093 & $0.254^{\star *}$ \\
\hline & $(1.50)$ & $(1.56)$ & $(3.31)$ \\
\hline \multirow[t]{2}{*}{ VTE per 100 capita (ambtelijke capaciteit) } & -0.199 & 0.083 & $-0.314^{*}$ \\
\hline & $(-1.24)$ & $(0.69)$ & $(-1.99)$ \\
\hline Politieke verandering & 0.042 & 0.005 & -0.001 \\
\hline $\mathrm{N}$ & 282 & 284 & 261 \\
\hline McFadden $\mathrm{R}^{2}$ & 0.07 & 0.246 & 0.142 \\
\hline Cragg-Uhler $\mathrm{R}^{2}$ & 0.096 & 0.259 & 0.185 \\
\hline
\end{tabular}

Standard errors tussen haakjes, * toont statistische significantie op $10 \%$, ** toont statistische significantie op $5 \%$, ${ }^{\star \star *}$ toont statistische significantie op $1 \%$.

Tabel 5 toont de regressie-resultaten. Geen van de modellen toont significante correlaties voor ambtelijke capaciteit (VTE), schaal of politieke verandering. Een uitzondering is echter het jeugdbeleid: het model toont een significant negatief effect $\left(b=-0,314^{*}\right)$ voor ambtelijke capaciteit (VTE), wat erop wijst dat lokale besturen met meer capaciteit in termen van VTE per 100 capita minder veranderingen hebben doorgevoerd. Betreffende sport en cultuur vinden we geen significante effec- 
ten voor VTE. De verklarende kracht van VTE lijkt dus beperkt of zelfs negatief, wat ingaat tegen de tweede theoretische verwachting die stelt dat lokale besturen met meer ambtelijke capaciteit meer beleidsvrijheid gebruiken. Dit is mogelijk te verklaren doordat een groter ambtelijk systeem meer weerstand kan bieden tegen verandering of doordat gemeenten met meer ambtelijke capaciteit reeds voor de hervorming heel wat maatwerk leverden waardoor ze de behoefte niet voelen om op nieuwe beleidsacties in te zetten.

Betreffende schaal en politieke verandering toont het regressiemodel geen significante verbanden. Er zijn geen aanwijzingen dat grotere gemeenten, of lokale besturen waar de partij van de burgemeester is veranderd, meer wijzigingen in hun budgettering hebben doorgevoerd. Het gebrek aan een significant effect van schaal en politieke verandering gaat in tegen de derde en vierde theoretische verwachting, die respectievelijk stellen dat gemeenten met een grotere schaal en gemeenten die politieke verandering hebben meegemaakt, meer formele beleidsvrijheid gebruiken. De resultaten liggen wel in lijn met de alternatieve versie van de vierde hypothese, die stelt dat politieke verandering geen verklaring is voor de beleidsvrijheid die gemeenten gebruiken.

Wanneer we kijken naar de verklaarde variantie van het model, valt op dat de $\mathrm{R}^{2}$-waarde klein is, wat naast het ontbreken van significante effecten erop wijst dat de verklarende kracht van ambtelijke capaciteit, schaal en politieke verandering zeer gering is. ${ }^{16}$ Deze variabelen zijn niet voldoende om variantie in gebruikte beleidsvrijheid te verklaren.

\section{Discussie en conclusie}

Lokale beleidsvrijheid wordt vaak gelijkgesteld aan de formele beleidsvrijheid van gemeenten en dus aan de formele grenzen die het speelveld bepalen (Fleurke \& Willemse, 2006; Keuffer \& Horber-Papazian, 2019). In dit artikel stelden we deze aanpak ter discussie. Het is namelijk onduidelijk in welke mate formele beleidsvrijheid een goede maat is voor de beleidsvrijheid die gemeenten benutten in de lokale beleidsvoering. Bovendien benut niet elke gemeente de formele beleidsvrijheid op dezelfde manier. Om variantie in gebruikte beleidsvrijheid te duiden wordt vaak verwezen naar ambtelijke capaciteit, schaal en recente politieke veranderingen. We onderzochten in welke mate deze variabelen wel degelijk verklarende kracht hebben voor de beleidsvrijheid die gemeenten gebruiken. Een hervorming in Vlaanderen (België) in 2016 bood de empirische context.

De resultaten tonen dat gemeenten de grotere formele beleidsvrijheid gebruiken. Sinds 2016 reserveren gemeenten een significant groter budgetaandeel voor lokale

Betreffende de Belfius-clusters vinden we een significant en positief effect voor drie clusters: gemeenten met een concentratie van economische activiteit, kustgemeenten en semi-stedelijke of agglomeratie-gemeenten. De significante resultaten wijzen erop dat gemeenten in deze drie clusters meer veranderingen in hun budgettering hebben doorgevoerd dan woongemeenten (de referentiegroep). 
beleidsacties. Deze bevinding ondersteunt het idee dat beleidsvrijheid een belangrijke voorwaarde is voor lokaal maatwerk en een goed functionerende lokale democratie (Bailey \& Elliott, 2009; Ladner e.a., 2019; Sharpe, 1970). De verschuiving van Vlaamse naar lokale beleidsacties is een indicatie dat gemeenten nu meer prioriteit geven aan 'echt' lokaal beleid en dus aan beleid dat responsief is voor de lokale context.

Niet alle gemeenten gebruiken de formele beleidsvrijheid in dezelfde mate. De analyse toont dat de verklarende kracht van ambtelijke capaciteit, schaal en politieke verandering gering is. Er is een meer diepgaande analyse nodig om variantie in gebruikte beleidsvrijheid te verklaren. Onderzoek naar agentschappen toont het belang van sociale interactie en netwerken (Maggetti \& Verhoest, 2014; Pollitt e.a., 2004; Verhoest, 2017; Verhoest e.a., 2004; Yesilkagit \& Van Thiel, 2008). In een netwerk ontstaat gedurende de jaren een eigen cultuur, welke tastbaar wordt in tradities, gewoonten, normen en waarden. De cultuur van een netwerk faciliteert (of belemmert) bepaalde beleidskeuzen (Fleurke \& Willemse, 2004; Gurr \& King, 1987; Jackson, 2014; Sedmihradska \& Bakos, 2016). Beleidsvrijheid is daarom niet iets wat een centrale overheid geeft, maar een sociaal construct dat wordt opgebouwd via interactie met diverse netwerkactoren, bijvoorbeeld de centrale overheid, het middenveld, de media en burgers (Maggetti \&Verhoest, 2014).

De democratische basis van lokale besturen maakt het bijna vanzelfsprekend dat netwerken ook relevant zijn voor de lokale beleidsvrijheid. Voornamelijk betreffende 'zichtbare' beleidsvelden zouden netwerken belangrijk zijn, aangezien daar de democratische controle het sterkst is (Arnold \& Carnes, 2012; Burstein, 2003; Burstein \& Linton, 2002; Einstein \& Kogan, 2016; Jones, 1994; Trounstine, 2010). Sport, jeugd en cultuur zijn dergelijke 'zichtbare' beleidsvelden. Het lokaal cultuur-, jeugd- en sportbeleid is immers nauw verbonden met het middenveld, dat grotendeels afhankelijk is van gemeentelijke subsidies en infrastructuur (Wilson, 2019). Lokale beleidsveranderingen hebben dan ook rechtstreeks impact op de cultuur-, jeugd-, en sportactiviteiten die het middenveld organiseert en waar burgers aan deelnemen. Die rechtstreekste impact kan ertoe leiden dat lokale netwerken korter op de bal spelen betreffende veranderingen in het sport-, jeugd- en cultuurbeleid en dus betreffende de beleidsvrijheid die gemeenten benutten. Er is daarom meer onderzoek nodig naar de impact van netwerken en sociale interactie (en ook de soft skills om met netwerken te interageren) op de beleidsvrijheid die lokale besturen gebruiken.

De resultaten hebben implicaties voor zowel theorie als praktijk. Enerzijds tonen de resultaten de beleidsmatige complexiteit tussen formele en gebruikte beleidsvrijheid. Centrale overheden focussen zich vaak op formele structuren en generieke variabelen, zoals het aantal personeelsleden en financiële middelen, om de lokale beleidsvrijheid uit te breiden. De resultaten tonen aan dat formele beleidsvrijheid een belangrijke stap is richting meer gebruikte beleidsvrijheid, maar ook dat generieke parameters onvoldoende zijn om variantie in gebruikte beleidsvrijheid te verklaren. Er is meer beleidsmatige en wetenschappelijke aandacht nodig voor de relevantie van niet-formele variabelen zoals netwerken, soft skills om te interageren 
met die netwerken en sociale interactie. Door niet enkel de formele kaders te hervormen vergroot mogelijk de effectiviteit van centraal beleid.

Anderzijds ondersteunen de resultaten de bevindingen van eerder wetenschappelijk onderzoek, maar breiden ze deze ook uit door empirisch aan te tonen hoe veranderingen in formele beleidsvrijheid een impact hebben op de beleidsvrijheid die gemeenten gebruiken. De resultaten dragen ook bij aan de inzichten over lokale democratie omdat ze empirisch aantonen dat het uitbreiden van de gemeentelijke beleidsvrijheid een belangrijke stap is richting meer lokaal maatwerk.

Onvermijdelijk heeft deze studie ook tekortkomingen. Ten eerste is de externe validiteit van de resultaten beperkt. We hebben beleidsvelden onderzocht waarvoor lokale besturen al een zekere formele beleidsvrijheid hadden en waarvoor de controle vanuit lokale beleidsnetwerken vrij groot is. De resultaten kunnen anders zijn voor andere beleidsvelden. Bovendien is Vlaanderen niet noodzakelijk vergelijkbaar met andere regio's en landen. De federale structuur, die bestaat uit gewesten en gemeenschappen, maakt dat de afstand tussen lokale besturen en de centrale overheid vrij klein is. Ook de relatief kleine schaal van Vlaamse gemeenten heeft mogelijk een impact op de verhouding tussen de lokale besturen en hun inwoners, alsook op de middelen waarover de lokale besturen beschikken.

Een tweede tekortkoming betreft de meting van de capaciteitsdimensie. Capaciteit gaat niet louter over het aantal voltijds equivalenten, maar ook over informatie, expertise en management en professionele skills (Verschuere, 2006; Wolman e.a., 2008). Door capaciteit louter te meten als VTE nemen we de impact van andere capaciteitsdimensies niet in rekening. Het doel van dit artikel was echter om de impact van VTE te analyseren, aangezien hier vaak naar verwezen wordt om variantie in gebruikte beleidsvrijheid te duiden. Andere capaciteitsdimensies zijn een relevante piste voor verder onderzoek.

In dit artikel hebben we de benadering die lokale beleidsvrijheid gelijkstelt aan formele beleidsvrijheid, ter discussie gesteld. De feitelijke beleidsvrijheid hangt namelijk niet enkel af van de formele beleidsvrijheid, maar ook van de mate waarin gemeenten gebruik weten te maken van de formele beleidsvrijheid. Daarnaast hebben we de impact van ambtelijke capaciteit, schaal en recente politieke veranderingen op gebruikte beleidsvrijheid in kaart gebracht. De resultaten tonen dat formele beleidsvrijheid een belangrijke stap is richting meer gebruikte beleidsvrijheid, maar ook dat generieke parameters niet voldoende zijn om variantie in gebruikte beleidsvrijheid te verklaren. Zowel in onderzoek als in beleid moet meer aandacht gaan naar de invloed van netwerken, soft skills om te interageren met die netwerken, sociale interactie en informatie en kennis op de beleidsvrijheid die gemeenten gebruiken in de beleidsvoering. 


\section{Literatuur}

Arnold, R.D. \& N. Carnes, 'Holding mayors accountable. New York's executives from Koch to Bloomberg', American Journal of Political Science, 2012/4, p. 949-963.

Asatryan, Z., L. Feld \& B. Geys, 'Partial fiscal decentralization and sub-national government fiscal discipline. Empirical evidence from OECD countries', Public Choice, 2015/3-4, p. 307-320.

Bailey, S. \& M. Elliott, 'Taking local government seriously. Democracy, autonomy and the constitution', Cambridge Law Journal, 2009/2, p. 436-472.

Bailey, M.A. \& M.C. Rom, 'A wider race? Interstate competition across health and welfare programs', The Journal of Politics, 2004/2, p. 326-347.

Benedictis-Kessner, J. de \& C. Warshaw, 'Mayoral partisanship and municipal fiscal policy', The Journal of Politics, 2016/4, p. 1124-1138.

Berman, D.R., Local government and the states. Autonomy, politics, and policy, Milton Park: 2019.

Börzel, T.A., T. Hofmann, D. Panke \& C. Sprungk, 'Obstinate and inefficient. Why member states do not comply with European law', Comparative Political Studies, 2020/11, p. 3631390.

Burstein, P., 'The impact of public opinion on public policy. A review and an agenda', Political Research Quarterly, 2003/1, p. 29-40.

Burstein, P. \& A. Linton, 'The impact of political parties, interest groups, and social movement organizations on public policy. Some recent evidence and theoretical concerns', Social Forces, 2002/2, p. 380-408.

Busuioc, M., 'Accountability, control and independence. The case of European agencies', European Law Journal, 2009/5, p. 599-615.

Cameron, A.C. \& P.K. Trivedi, Microeconometrics. Methods and application, Cambridge: 2005.

Cao, H.H., B. Han, D. Hirshleifer \& H.H. Zhang, 'Fear of the unknown. Familiarity and economic decisions', Review of Finance, 2011/1, p. 173-206.

Christensen, T. \& P. Lægreid, 'Agentification and regulatory reforms', T. Christensen \& P. Lægreid (eds.), Autonomy and regulation. Coping with agencies in the modern state, Cheltenham: 2006, p. 8-50.

Cottle, S., 'Reporting demonstrations. The changing media politics of dissent', Media, Culture \& Society, 2008/6, p. 853-872.

Craw, M., 'Overcoming city limits. Vertical and horizontal models of local redistributive policy making', Social Science Quarterly, 2006/2, p. 361-379.

Dewan, T. \& D.P. Myatt, 'Leading the party. Coordination, direction, and communication', American Political Science Review, 2007/4, p. 827-845.

Egeberg, M. \& J. Trondal, 'National agencies in the European administrative space. Government driven, commission driven or networked?', Public Administration, 2009/4, p. 779790.

Einstein, K.L. \& V. Kogan, 'Pushing the city limits. Policy responsiveness in municipal government', Urban Affairs Review, 2016/1, p. 3-32.

Eyraud, L. \& L. Lusinyan, 'Vertical fiscal imbalances and fiscal performance in advanced economies', Journal of Monetary Economics, 2013/5, p. 571-587.

Fernandez, S., J.E. Ryu \& J.L. Brudney, 'Exploring variations in contracting for services among American local governments. Do politics still matter?', The American Review of Public Administration, 2008/4, p. 439-462.

Ferreira, F. \& J. Gyourko, 'Do political parties matter? Evidence from US cities', The Quarterly Journal of Economics, 2009/1, p. 399-422.

Ferreira, F. \& J. Gyourko, 'Does gender matter for political leadership? The case of US mayors', Journal of Public Economics, 2014, Volume 112, p. 24-39. 
Fleurke, F. \& R. Willemse, 'Approaches to decentralization and local autonomy. A critical appraisal', Administrative Theory \& Praxis, 2004/4, p. 523-544.

Fleurke, F. \& R. Willemse, 'Measuring local autonomy. A decision-making approach', Local Government Studies, 2006/1, p. 71-87.

Galasso, V. \& T. Nannicini, 'Competing on good politicians', American Political Science Review, 2011/1, p. 79-99.

Gerber, E.R. \& D.J. Hopkins, 'When mayors matter. Estimating the impact of mayoral partisanship on city policy', American Journal of Political Science, 2011/2, p. 326-339.

Greffe, X., 'Decentralisation. What difference does it make? A synthesis', S. Giguère (ed.), Managing decentralisation. A new role for labour market policy, OECD, Parijs: 2006, p. 3164.

Groenleer, M.L.P., The autonomy of European Union agencies. A comparative study of institutional development, proefschrift Universiteit Leiden, Delft: 2009.

Gurr, T.R. \& D.S. King, The state and the city, Chicago, IL: 1987.

Hansen, T. \& J.E. Klausen, 'Between the welfare state and local government autonomy', Local Government Studies, 2002/4, p. 47-66.

Hills, R.M. jr., 'The political economy of cooperative federalism. Why state autonomy makes sense and dual sovereignty doesn't', Michigan Law Review, 1997/4, p. 813-944.

Hooghe, L. \& G. Marks, 'Beyond federalism. Estimating and explaining the territorial structure of government', Publius: The Journal of Federalism, 2012/2, p. 179-204.

Hopkins, D.J. \& K.T. McCabe, 'After it's too late. Estimating the policy impacts of black mayoralties in US Cities', American Politics Research, 2012/4, p. 665-700.

Huckfeldt, R., E. Plutzer \& J. Sprague, 'Alternative contexts of political behavior. Churches, neighborhoods, and individuals', The Journal of Politics, 1993/2, p. 365-381.

Hulst, J.R. \& A.J.G.M. van Montfort, 'Inter-municipal cooperation. A widespread phenomenon', J.R. Hulst \& A.J.G.M. van Montfort (eds.), Inter-municipal cooperation in Europe, Dordrecht: 2007, p. 1-21.

Jackson, C., 'Structural and behavioural independence. Mapping the meaning of agency independence at the field level', International Review of Administrative Sciences, 2014/2, p. 257-275.

Jones, B.D., Reconceiving decision-making in democratic politics. Attention, choice, and public policy, Chicago, IL: 1994.

Jones, B.F. \& B.A. Olken, 'Do leaders matter? National leadership and growth since World War II', The Quarterly Journal of Economic, 2005/3, p. 835-864.

Keuffer, N. \& K. Horber-Papazian, 'The bottom-up approach. Essential to an apprehension of local autonomy and local governance in the case of Switzerland', Local Government Studies, 2019/2, p. 1-20.

Koch, S. \& N. Molenaers, 'The Europeanisation of budget support. Do government capacity and autonomy matter?', European Politics and Society, 2016/1, p. 90-104.

Ladner, A., N. Keuffer, H. Baldersheim, N. Hlepas, P. Swianiewicz, K. Steyvers \& C. Navarro, 'What is local autonomy?', H. Baldersheim, N. Hlepas, P. Swianiewicz, K. Steyvers \& C. Navarro (eds.), Patterns of local autonomy in Europe, Cham: 2019, p. 3-36.

Lake, R.W., 'Negotiating local autonomy', Political Geography, 1994/5, p. 423-442.

Larson, A.M. \& J.C. Ribot, 'Democratic decentralisation through a natural resource lens: an introduction', The European Journal of Development Research, 2004/1, p. 1-25.

Leigh, A., 'Estimating the impact of gubernatorial partisanship on policy settings and economic outcomes. A regression discontinuity approach', European Journal of Political Economy, 2008/1, p. 256-268.

Lipsky, M., 'Street-level bureaucracy. An introduction', M. Hill (ed.), The policy process. A reader, Londen: 1993, p. 381-385.

Lipsky, M., Street-level bureaucracy. Dilemmas of the individual in public service, New York: 2010. 
Maestas, C., J. Chattopadhyay, S. Leland \& J. Piatak, 'Fearing food. The influence of risk perceptions on public preferences for uniform and centralized risk regulation', Policy Studies Journal, 2020/2, p. 447-468.

Maggetti, M., 'De facto independence after delegation. A fuzzy-set analysis', Regulation \& Governance, 2007/4, p. 271-294.

Maggetti, M., Regulation in practice. The de facto independence of regulatory agencies, ECPR, Colchester: 2012.

Maggetti, M. \& K. Verhoest, 'Unexplored aspects of bureaucratic autonomy. A state of the field and ways forward', International Review of Administrative Sciences, 2014/2, p. 239256.

McAllister, L.K., 'Dimensions of enforcement style. Factoring in regulatory autonomy and capacity', Law \& Policy, 2010/1, p. 61-78.

Meier, K.J. \& R.E. England, 'Black representation and educational policy. Are they related?', American Political Science Review, 1984/2, p. 392-403.

Mello, L.R. de, 'Fiscal decentralization and intergovernmental fiscal relations. A cross-country analysis', World Development, 2000/2, p. 365-380.

Morgan, D.R. \& S. Watson, 'The effects of mayoral power on urban fiscal policy', Policy Studies Journal, 1995/2, p. 231-243.

Mulé, R., Political parties, games and redistribution, Cambridge: 2001.

Nelles, J., 'Cooperation and capacity? Exploring the sources and limits of city-region governance partnerships', International Journal of Urban and Regional Research, 2013/4, p. 1349-1367.

Nivola, P.S., Tense commandments. Federal prescriptions and city problems, Brookings Institution, Wahington, DC: 1996.

Painter, M. \& W.H. Yee, 'Task matters. A structural-instrumental analysis of the autonomy of Hong Kong government bodies', The American Review of Public Administration, 2010/4, p. 395-410.

Pelissero, J.P., D.B. Holian \& L.A. Tomaka, 'Does political incorporation matter? The impact of minority mayors over time', Urban Affairs Review, 2000/1, p. 84-92.

Peters, B.G., 'Managing horizontal government. The politics of co-ordination', Public Administration, 1998/2, p. 295-311.

Pollitt, C., C. Talbot, J. Caulfield \& A. Smullen, Agencies. How governments do things through semi-autonomous organizations, Cham: 2004.

Pratchett, L., 'Local autonomy, local democracy and the "New Localism"', Political Studies, 2004/2, p. 358-375.

Rae, D., City. Urbanism and its end, New Haven, CT: 2003.

Rekenhof, Verslag van het Rekenhof over interbestuurlijke verhoudingen tussen de Vlaamse overheid en de steden en gemeenten, na de integratie van sectorale subsidies in de algemene financiering, Brussel: 2019.

Schmidt, M.G., 'When parties matter. A review of the possibilities and limits of partisan influence on public policy', European Journal of Political Research, 1996/2, p. 155-183.

Sedmihradska, L. \& E. Bakos, 'Municipal tax autonomy and tax mimicking in Czech municipalities', Lex Localis, 2016/1, p. 75-92.

Self, R.O., American Babylon. Race and the struggle for postwar Oakland, Politics and Society in Modern America Book 34, Princeton, NJ: 2005.

Sharpe, L.J., 'Theories and values of local government', Political Studies, 1970/2, p. 153-174.

Tausanovitch, C. \& C. Warshaw, 'Representation in municipal government', American Political Science Review, 2014/3, p. 605-641.

Tiebout, C.M., 'A pure theory of local expenditures', Journal of Political Economy, 1956/5, p. $416-424$.

Trounstine, J., 'Representation and accountability in cities', Annual Review of Political Science, 2010, Volume 13, p. 407-423. 
Verhoest, K., 'Agencification in Europe', E. Ongaro \& S.van Thiel (eds.), The Palgrave Handbook of public Administration and Management in Europe, Basingstoke: 2017.

Verhoest, K., B.G. Peters, G. Bouckaert \& B. Verschuere, "The study of organisational autonomy. A conceptual review', Public Administration and Development, 2004/2, p. 101-118.

Verschuere, B., Autonomy \& control in arm's length public agencies. Exploring the determinants of policy autonomy, proefschrift Katholieke Universiteit Leuven, Leuven: 2006.

Verschuere, B. \& J. De Corte, 'Nonprofit advocacy under a third-party government regime. Cooperation or conflict?', VOLUNTAS: International Journal of Voluntary and Nonprofit Organizations, 2015/1, p. 222-241.

Walker, R.M., F.S. Berry \& C.N. Avellaneda, 'Limits on innovativeness in local government. Examining capacity, complexity, and dynamism in organizational task environments', Public Administration, 2015/3, p. 663-683.

Wattenberg, M.P., ‘The decline of party mobilization', R.J. Dalton \& M.P. Wassenberg (eds.), Parties without partisans. Political change in advanced industrial democracies, Oxford: 2000, p. 64-76.

Wildavsky, A. \& K. Dake, 'Theories of risk perception. Who fears what and why?', Daedalus, 1990/4, p. 41-60.

Wilson, J., Politics and leisure, Milton Park: 2019.

Wolman, H., R. McManmon, M. Bell \& D. Brunori, Comparing local government autonomy across states, working paper 35, George Washington Institute for Public Policy, Washington, DC: 2008.

Wolman, H., J. Strate \& A. Melchior, 'Does changing mayors matter?', The Journal of Politics, 1996/1, p. 201-223.

Yesilkagit, K. \& S. van Thiel, 'Political influence and bureaucratic autonomy', Public Organization Review, 2008/2, p. 137-153.

Zito, A.R., 'Expertise and power. Agencies operating in complex environments', Politics and Governance, 2015/1, p. 73-89. 
Bijlage

Tabel A Vlaamse beleidsprioriteiten voor jeugd, sport en cultuur

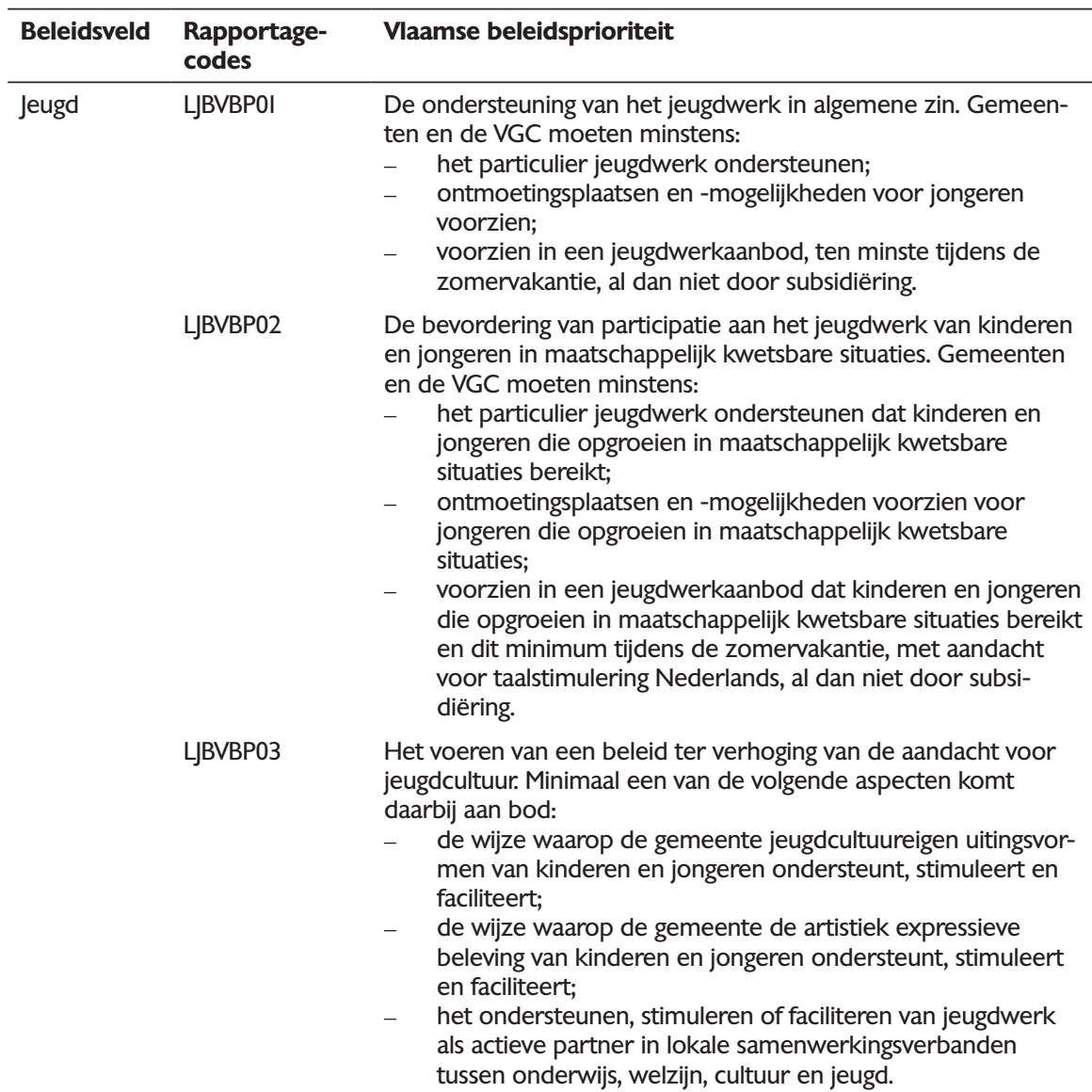

Sport LSBVBPOI

LSBVBP02

LSBVBP03

LSBVBP04

LSBVBP05

(enkel voor de provincies)
Het ondersteunen van de kwalitatieve uitbouw van de sportverenigingen via een doelgericht subsidiebeleid.

Het stimuleren van sportverenigingen tot professionalisering met een bijzonder accent op kwaliteitsvolle jeugdsportbegeleiding en eventueel tot onderlinge samenwerking.

Het voeren van een activeringsbeleid met het oog op een levenslange sportparticipatie via een anders georganiseerd, laagdrempelig beweeg- en sportaanbod.

Het voeren van een beweeg- en sportbeleid met aandacht voor transversale samenwerking zodat kansengroepen gelijke kansen krijgen om actief te participeren in sport.

Het stimuleren van personen met een handicap tot sportbeoefening via een laagdrempelig beweeg- en sportaanbod. 
Tabel A (Vervolg)

\begin{tabular}{lll}
\hline Beleidsveld & $\begin{array}{l}\text { Rapportage- } \\
\text { codes }\end{array}$ & Vlaamse beleidsprioriteit \\
\hline Cultuur & LCBVBPOI & $\begin{array}{l}\text { De gemeente voert een kwalitatief en duurzaam lokaal } \\
\text { cultuurbeleid. Deze beleidsprioriteit wordt als volgt gespecifi- } \\
\text { ceerd: de gemeente ontwikkelt een integraal en duurzaam } \\
\text { cultuurbeleid, met bijzondere aandacht voor gemeenschapsvor- } \\
\end{array}$ \\
& ming, cultuureducatie en het bereiken van kansengroepen.
\end{tabular}

LCBVBP02 De gemeente richt een laagdrempelige bibliotheek in, aangepast aan de hedendaagse noden. Deze beleidsprioriteit wordt als volgt gespecificeerd: de gemeente beschikt over een openbare bibliotheek die:

- de cultuureducatie en de leesmotivatie stimuleert;

- $\quad$ inzet op de bevordering van e-inclusie bij moeilijk bereikbare doelgroepen en op de verhoging van informatiegeletterdheid en mediawijsheid;

- $\quad$ inzet op een aangepaste dienstverlening voor personen met beperkte mobiliteit en voor moeilijk bereikbare doelgroepen op cultureel, educatief en sociaaleconomisch gebied;

- $\quad$ inzet op samenwerking met onderwijsinstellingen.

LCBVBP03 De gemeente, opgenomen in de lijst van steden en gemeenten die als bijlage bij het decreet is gevoegd, richt een cultuurcentrum in. Deze beleidsprioriteit wordt als volgt gespecificeerd:

- de gemeente beschikt over een cultuurcentrum dat een eigen cultuuraanbod met een lokale en regionale uitstraling realiseert dat inspeelt op de vragen en behoeften van diverse bevolkingsgroepen en aandacht heeft voor een spreiding van en wisselwerking met door de Vlaamse overheid gesubsidieerde en ondersteunde gezelschappen;

- $\quad$ actief ondersteuning biedt aan amateurkunsten en (sociaal-) culturele verenigingen;

- $\quad$ inzet op een aangepast aanbod van kunst en cultuureducatie in samenwerking met relevante actoren.

LCBVBP04 Om de subsidie te verkrijgen moeten de steden Antwerpen en Gent lokale invulling geven aan de volgende Vlaamse beleidsprioriteit: de stad voert een integraal lokaal cultuurbeleid, met aandacht voor alle culturele sectoren, waarbij ze:

- $\quad$ vertrekt vanuit de demografische samenstelling van de stad met het oog op de participatie van alle mogelijke doelgroepen in de stad;

- $\quad$ een beleid ontwikkelt op het vlak van cultuureducatie dat minstens inzet op levenslang leren, mediageletterdheid en de bevordering van de culturele competentie;

- $\quad$ een kunstenbeleid ontwikkelt dat inzet op het brede spectrum van amateurkunstenaars, individuele kunstenaars en professionele kunstinstellingen op het grondgebied. 


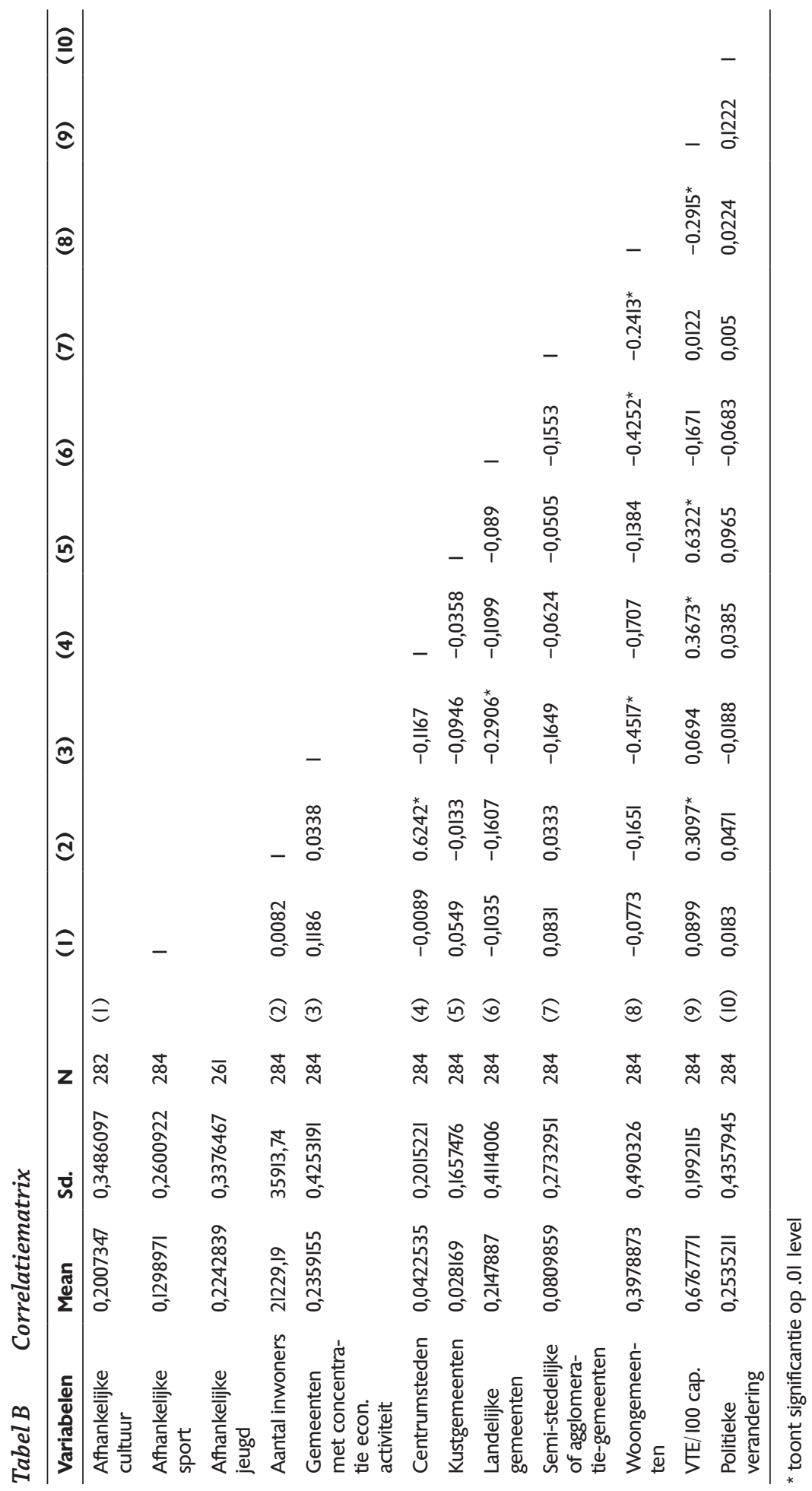

